\title{
The karabus affair speaks to larger issues for american academic and medical centers.
}

\author{
Leonard A Zwelling, MD, MBA \\ Houston $T X$ \\ Razelle Kurzrock, MD \\ San Diego, CA \\ Philip R Cohen, MD \\ San Diego, CA \\ Bernard Levin, MD, Ch \\ New York, NY \\ Follow this and additional works at: https://jdc.jefferson.edu/dcbfp \\ Lawrence Parish, MD

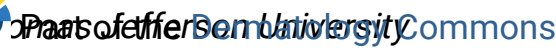 \\ Let us know how access to this document benefits you
}

\section{Recommended Citation}

Zwelling, MD, MBA, Leonard A; Kurzrock, MD, Razelle; Cohen, MD, Philip R; Levin, MD, Ch, Bernard; and Parish, MD, Lawrence, "The karabus affair speaks to larger issues for american academic and medical centers." (2013). Department of Dermatology and Cutaneous Biology Faculty Papers. Paper 13.

https://jdc.jefferson.edu/dcbfp/13

This Article is brought to you for free and open access by the Jefferson Digital Commons. The Jefferson Digital Commons is a service of Thomas Jefferson University's Center for Teaching and Learning (CTL). The Commons is a showcase for Jefferson books and journals, peer-reviewed scholarly publications, unique historical collections from the University archives, and teaching tools. The Jefferson Digital Commons allows researchers and interested readers anywhere in the world to learn about and keep up to date with Jefferson scholarship. This article has been accepted for inclusion in Department of Dermatology and Cutaneous Biology Faculty Papers by an authorized administrator of the Jefferson Digital Commons. For more information, please contact: JeffersonDigitalCommons@jefferson.edu. 


\title{
As submitted to:
}

\section{Clinics in Dermatology}

\author{
And later published as:
}

$\underline{\text { Letter from the Editor }}$

Edited by Stephen P.Stone, MD

\section{The Karabus Affair Speaks to Larger Issues for American Academic and Medical Centers}

\author{
Volume 31, Issue 3, May 2013, Pages 325-326 \\ DOI: 10.1016/j.clindermatol.2013.03.001
}

Leonard A. Zwelling, MD, MBA, Razelle Kurzrock, MD, Philip R. Cohen, MD, Bernard Levin, MB, CH (Rand) and Lawrence Charles Parish, MD, MD (Hon)

Finally, on March 12, 2013, a major American newspaper, The Wall Street Journal, reported on the plight of Dr. Cyril Karabus $(1,2)$. Dr. Karabus is the 78 year old pediatric oncologist from Claremont, Capetown, South Africa who is well known as the retired head of the Oncology and Hematology Unit of the Red Cross Children's Hospital, University of Cape Town, as well as for his devoted service to poor children in the apartheid era. In 2002, he cared for a three-year old Yemeni girl with acute myelogenous leukemia during a locum tenens in the United Arab Emirates (UAE).

\section{Background}

Flying back to South Africa from his son's wedding in Toronto, the doctor and his family passed through the airport in Abu Dhabi on August 17, 2012. As they were boarding their flight back to South Africa the next day, the doctor was arrested. Only then did he learn that he had been tried in absentia several years earlier and found guilty of manslaughter following the death of his patient. He was imprisoned in the hospital wing of the Al Wathba Prison. Not until there were 5 court appearances was the frail doctor with a heart condition freed on bail despite his 
having competent legal representation. He was unable to return home as his passport had been confiscated and he was still to be retried. This punitive action was described in this publication by three of us (3; PRC, RK and LCP) and in the Cancer Letter by two of us (4; BL and LZ).

\section{Press Coverage}

This injustice did not go unnoticed in the rest of the English-speaking world's press. It was, however, not even a blip on the news services within the United States confirmed by multiple searches on the internet. Why not?

Reports appeared in major British publications including the Economist (5) and the British Medical Journal (6). Several of us wrote opinion pieces for American newspapers, but none were accepted for publication including by the New England Journal of Medicine, the New York Times and Wall Street Journal. Through both this Journal and the Cancer Letter, we raised awareness of the doctor's plight. We all believed that this was a major tale of a justice system that went haywire and an American press that did not take notice of a story occurring in a country with which Americans have both professional and commercial ties.

\section{A Raison d'etre}

But there are good reasons for the American press to note this story. In fact, there are millions of them-dollars and barrels.

The UAE is governed by the Zayed family. The Zayeds have made huge contributions to Johns Hopkins University in Baltimore (Sheikh Zayed Tower houses the Hopkins Heart and Vascular Institute) (7), The Children's National Medical Center in Washington, DC (The Sheikh Zayed Institute for Pediatric Surgical Intervention) (8), and The University of Texas MD Anderson Cancer Center (The Sheikh Zayed Bin Sultan Al Nahyan Building for Personalized Cancer Care) (9). The Zayed's have contributed to other academic institutions, as well, including the London School of Economics and the Harvard Divinity School. In the latter case, one student, Rachel Lea Fish, forced the return of a donation of over $\$ 2 \mathrm{M}$, when she discovered that the source of the donation was the Zayed Center for Coordination and Follow-Up, an organization that engaged in virulent anti-Semitic and antiAmerican discourse. Soon after, the Zayed Center was disbanded (10).

But the money keeps coming in to the United States, and the academic institutions are more than willing to accept it. The donors of these funds oversee an oligarchic dictatorship with a justice system in which guilt is presumed, and the onus of innocence falls upon the accused. As of this writing, it appears possible that Dr. Karabus will be released presently after 7 months in captivity, as the medical records needed to convict him or for him to exonerate himself cannot be found. But we have read of his imminent release for months now, and our hopes have been dashed before. 


\title{
Conclusions
}

The larger issue is whether supposed bastions of truth like American universities and academic medical centers named above ought to be taking large sums of money from foreign dictatorships. Not so very long ago, Sir Howard Davies of the esteemed London School of Economics resigned in disgrace after having a far too cozy relationship with Colonel Gaddafii, formerly of Libya. The Colonel's son had been admitted to the school, despite not having the credentials and the Colonel himself appeared on a live video link at the school "denouncing the Lockerbie bombing as a fabrication." (11).

Harvard and Georgetown Universities have taken millions of dollars from the House of Saud as have the University of California at Berkeley and the University of Arkansas. The events at the London School of Economics demonstrated that supposedly string-less philanthropy can mold the world-view of recipient institutions. It is, therefore, relevant to ask whether or not the behavior and policies of donors should be considered when accepting foreign largesse (11).

It may also be prudent for the recipients of financial donations from foreign governments with systems of justice unlike our own take steps to secure the safety of any personnel flying into, and hopefully out of, these donor countries.

\author{
Leonard A. Zwelling, MD, MBA, \\ Houston, TX \\ Razelle Kurzrock, MD, \\ and \\ Philip R. Cohen, MD \\ San Diego, CA \\ Bernard Levin, MB, CH (Rand) \\ New York, NY \\ Lawrence Charles Parish, MD, MD (Hon) \\ Department of Dermatology and Cutaneous \\ Biology \\ and Jefferson Center for International \\ Dermatology \\ Jefferson Medical College of Thomas Jefferson \\ University \\ Philadelphia, PA, USA
}

\section{References}


1 Cotler, I, A Doctor's Nightmare Stopover in Dubai, The Wall Street Journal, p. A17, March 12, 2013.

2. Zwelling, LA, Kurzrock, R, Cohen, PR, Doctor Nab in Dubai and Donations, The Wall Street Journal, p. A16, March 19, 2013.

3.Cohen, PR, Kurzrock R, Parish LC. Warning signal: unaware of an in absentia conviction, South African cancer specialist jailed on return to the United Arab Emirates. Clin Dermatol. 2013;31:128-130.

4. Levin B, Zwelling L, The Cancer Letter, 38 (46):11, 2012.

5. Waiting for Justice, The Economist, November 1, 2012, http://www.economist.com/blogs/pomegranate/2012/11/united-arab-emirates

6. Nathanson, $\mathrm{V}$, The imprisonment of Cyril Karabus is deplorable, Br. Med J., October 9, 2012, http:www.bmj.com/content/345/bmj.e6815.pdf\%2Bhtml

7. Sheikh Zayed Tower, http://www.hopkinsmedicine.org/se/util

8. About the gift-Sheikh Zayed Institute for Pediatric Surgical Innovation, http://www.childrensnational.org/print/SheikhZayedSurgicaliinstitute/aboutgift.aspx

9. Moukheiber, Z, Another Multi-Million Dollar Gist to U.S. Hospital from Billionaire Arab Ruler, Forbes, http://www.forbes.com/sites/zinamoukheiber/2011/01.19/another-milliondollar-gift-to-u-s-hospital-from -billionaire-arab-ruler

10. Jaffit, J, http://jcpa.org/article/fighting-sheikh-zayeds-funding -of-islamicstudies-at-harvard-divinity-school-a-case-study

11. Tan, S, Dangerous Liaisons, The PoliticL:A Yale Undergraduate Journal of Politics, April 21, 2012, http://thepoltic.org/?p=1374 